\title{
Copper and cadmium effects on growth and extracellular exudation of the marine toxic dinoflagellate Alexandrium catenella: 3D-fluorescence spectroscopy approach
}

\author{
Faouzi Herzi $^{\mathrm{a}, \mathrm{b}}$, Natacha Jean ${ }^{\mathrm{b}}$, Huiyu Zhao ${ }^{\mathrm{b}}$, Stéphane Mounier ${ }^{\mathrm{b}, *}$, Hassine Hadj Mabrouk ${ }^{\mathrm{a}}$, \\ Asma Sakka Hlaili ${ }^{\text {a }}$ \\ a Université de Carthage, Faculté des Sciences de Bizerte, LCVP, 7021 Jarzouna, Bizerte, Tunisia \\ ${ }^{\mathrm{b}}$ Université de Toulon, PROTEE, EA 3819, 83957 La Garde, France
}

\section{H I G H L I G H T S}

- Effects of trace metals on growth kinetics of the marine toxic dinoflagellate Alexandrium catenella.

- Effects of trace metals on organic exudates from the marine toxic dinoflagellate A. catenella.

- A. catenella is a species tolerant to high trace metal concentrations.

- Release of Fluorescent Dissolved Organic Matter by toxic phytoplankton could play an important role in metal speciation.

- Defence mechanisms set up by the toxic dinoflagellate against metal stress.

Keywords:

Metals

DOC

3D-fluorescence spectroscopy

PARAFAC

Alexandrium catenella

Toxic dinoflagellate

\begin{abstract}
A B S T R A C T
In this study, metal contamination experiments were conducted to investigate the effects of copper and cadmium on the growth of the marine toxic dinoflagellate Alexandrium catenella and on the production of dissolved organic matter (Dissolved Organic Carbon: DOC; Fluorescent Dissolved Organic Matter: FDOM) This species was exposed to increasing concentrations of $\mathrm{Cu}^{2+}\left(9.93 \times 10^{-10}-1.00 \times 10^{-7} \mathrm{M}\right)$ or $\mathrm{Cd}^{2+}$ $\left(1.30 \times 10^{-8}-4.38 \times 10^{-7} \mathrm{M}\right)$, to simulate polluted environments. The drastic effects were observed at $\mathrm{pCu}^{2+}=7.96\left(\mathrm{Cu}^{2+}: 1.08 \times 10^{-8} \mathrm{M}\right)$ and $\mathrm{pCd}^{2+}=7.28\left(\mathrm{Cd}^{2+}: 5.19 \times 10^{-8} \mathrm{M}\right)$, where cyst formation occurred. Lower levels of $\mathrm{Cu}^{2+}\left(\mathrm{pCu}^{2+}>9.00\right)$ and $\mathrm{Cd}^{2+}\left(\mathrm{pCd}^{2+}>7.28\right)$ had no effect on growth. However, when levels of $\mathrm{Cu}^{2+}$ and $\mathrm{Cd}^{2+}$ were beyond $10^{-7} \mathrm{M}$, the growth was totally inhibited. The DOC released per cell (DOC/Cell) was different depending on the exposure time and the metal contamination, with higher DOC/Cell values in response to $\mathrm{Cu}^{2+}$ and $\mathrm{Cd}^{2+}$, comparatively to the control. Samples were also analyzed by 3D-fluorescence spectroscopy, using the Parallel Factor Analysis (PARAFAC) algorithm to characterize the FDOM. The PARAFAC analytical treatment revealed four components ( $\mathrm{C} 1, \mathrm{C} 2, \mathrm{C} 3$ and $\mathrm{C} 4)$ that could be associated with two contributions: one, related to the biological activity; the other, linked to the decomposition of organic matter. The $\mathrm{C} 1$ component combined a tryptophan peak and a characteristic humic substances response, and the $\mathrm{C} 2$ component was considered as a tryptophan protein fluorophore. The C3 and C4 components were associated to marine organic matter production.
\end{abstract}

Abbreviations: CFP, Ciguatera Fish Poisoning; CDA, Controlled Dilution Approach; DOC, Dissolved Organic Carbon; DOM, dissolved organic matter; EEM, Excitation-Emission Matrix of Fluorescence; FDOM, Fluorescent Dissolved Organic Matter; HAB, Harmful Algal Bloom; NSP, Neurotoxic Shellfish Poisoning; PARAFAC, Parallel Factor Analysis; PSP, Paralytic Shellfish Poisoning.

* Corresponding author. Tel.: +33 4941428 29; fax: +33 494142168

E-mail addresses: faouzi-herzi@univ-tln.fr (F. Herzi), jean@univ-tln.fr (N. Jean), huiyu.zhao@univ-tln.fr (H. Zhao), mounier@univ-tln.fr (S. Mounier), asma_sakka@yahoo.fr (A.S. Hlaili).

\section{Introduction}

Dinoflagellates are responsible for $75 \%$ of the marine harmful algal blooms (HABs) (Chan et al., 2002). They may induce various syndromes such as: The Neurotoxic Shellfish Poisoning (NSP), the Paralytic Shellfish Poisoning (PSP) and the Ciguatera Fish Poisoning (CFP) (Glibert et al., 2005). Over the last decades, the frequency and the distribution of HABs have increased in marine coastal ecosystems (Sellner et al., 2003). As a result, although it has not yet been 
really demonstrated, eutrophication forced by anthropogenic inputs could partially explain the HAB expansion (Glibert et al., 2005). Among the dinoflagellates, Alexandrium genus is one source of HABs. Blooms of Alexandrium have been reported in various marine waters, such as the northwest Mediterranean (Penna et al., 2005), the coastal waters of Chile (Cordova and Muller, 2002), Tunisia (Turki and Balti, 2005), Algeria (Frehi et al., 2007), and in France (Thau lagoons) (Lilly et al., 2002).

In a polluted coastal marine ecosystem (Toulon Bay, France), the dinoflagellates were predominant relatively to other phytoplankton groups like diatoms (Jean et al., 2005). In this ecosystem, where metal contamination has been reported (Tessier et al., 2011), Alexandrium bloomed at some periods of the year (Jean et al., 2006), suggesting that this genus could be tolerant to metal contamination.

In marine ecosystems, metal cations are complexed by natural inorganic and organic ligands. This complexation leads to a competition between natural ligands present in organic matter, inorganic anions, and membrane transport proteins for binding metal cations, which change the bioavailability of the metal for the cell (Sunda and Hunstman, 1998). As a result, complexation of metals by natural organic ligands often decreases their toxicity in aquatic environments (Moffett et al., 1990). Hence, metal toxicity towards organisms does not only depend on the total metal concentration, but essentially on the metal cation chemical speciation, which can be calculated on the basis of the free ion activity model (Sunda and Guillard, 1976). The natural organic ligands capable of metal complexation can have a biological origin, as the phytochelatine, which is produced by phytoplankton for the metal detoxication (Le Faucheur et al., 2005). Moreover, organic ligands released by phytoplankton can modify trace metal speciation (Vasconcelos et al., 2002). Therefore, the studies characterizing the DOM released by phytoplankton under stress metal conditions should bring a better knowledge of the DOM implication in the metal availability for phytoplankton. This DOM can be monitored by 3D-fluorescence spectroscopy approach.

The fluorescence spectroscopy technique has been applied to characterize DOM coming from various environments. Successive advances in fluorescence analysis have improved the method, from 1-dimension (Vodacek et al., 1997), and then, 2-dimensions (Lloyd, 1971), to a powerful technique based on the Excitation-Emission Matrices of fluorescence (EEMs). Studies on Fluorescent Dissolved Organic Matter (FDOM) have been carried out from samples collected in many types of aquatic ecosystems, such as rivers (Mounier et al., 1999), estuaries (Jaffé et al., 2004), benthic (sediment pore water) or polluted areas (Burdige, 2004), biological cultures (Parlanti et al., 2000) and marine ecosystems (Kowalczuk et al., 2005). To improve identification of fluorescent compounds, the PARAFAC algorithm is applied as a statistical EEMs treatment (Bro, 1997). Thanks to PARAFAC, the FDOM can be mathematically identified, leading to the optimal separation of fluorescent components. Other algorithms have helped to non linear corrections: the elimination of Rayleigh and Raman scatterings (Zepp et al., 2004), the statistical method Concordia (Bro and Kiers, 2003), and an inner filter effect correction using the Controlled Dilution Approach (CDA) (Luciani et al., 2009). PARAFAC has been successfully used to investigate the FDOM origins in aquatic samples from estuarine (Luciani et al., 2008), marine (Murphy et al., 2008) and freshwater ecosystems (Holbrook et al., 2006), and it also has been applied to soil-extracted DOM (Banaitis et al., 2006). However, to our knowledge, no study mentions the use of PARAFAC to characterize FDOM released by phytoplankton grown in cultures contaminated by metals.

The first objective of this study is to examine the effects of the two trace metals, copper and cadmium, on the growth of Alexandrium catenella, in order to explore the physiological response of this dinoflagellate to metal stress. A second objective is to characterize the FDOM released by $A$. catenella cultures submitted to increasing $\mathrm{Cu}$ and $\mathrm{Cd}$ concentrations. This characterization, based on DOC analysis, and on FDOM 3D-fluorescence results treated by PARAFAC, aimed at investigating the links potentially existing between FDOM exudates and metal contamination as a result of $A$. catenella stress reaction.

\section{Materials and methods}

\subsection{Alexandrium catenella cultures}

A strain of A. catenella (АСТ03) was isolated from the Thau lagoon (France) in 2003, by the Laboratory Ecologie des Systèmes Marins Côtiers (ECOSYM UMR 5119, Université Montpellier 2, CNRS, Ifremer and IRD). The cultures from this strain were maintained in $\mathrm{f} / 2$ medium prepared in $0.2 \mu \mathrm{m}$ polycarbonate filtered and sterilized natural low contaminated seawater. The cultures were grown at $+20{ }^{\circ} \mathrm{C}$ in sterile $250 \mathrm{~mL}$ flasks exposed to $135 \mu \mathrm{mol}$ photons $\mathrm{m}^{-2} \mathrm{~s}^{-1}$ during light:dark cycle of $12 \mathrm{~h}: 12 \mathrm{~h}$.

To study the effects of metal contamination on the growth, on DOC and on the FDOM responses, culture medium was supplemented with two different solutions of the studied metals, prepared in ultrapure water with $\mathrm{CuSO}_{4}, 2 \mathrm{H}_{2} \mathrm{O}$ or with $3 \mathrm{CdSO}_{4}$, $8 \mathrm{H}_{2} \mathrm{O}$ salts. For each metal, different levels of contamination were achieved thanks to eight different total concentrations $(3,6,12,16$, $18,25,60$ and $100 \mu \mathrm{M})$. Growth conditions were labeled as following: $\mathrm{Cd}_{i}$ or $\mathrm{Cu}_{j}$, where $i$ and $j$ are the total metal concentrations expressed in $\mu \mathrm{M}$. Based on the MINEQL-program and on the known composition of the $\mathrm{f} / 2$ solution, the corresponding $\mathrm{Cu}^{2+}$ and $\mathrm{Cd}^{2+}$ were calculated, and reported in $\mathrm{pM}^{2+}$ units. The $\mathrm{pCu}^{2+}$ and $\mathrm{pCd}^{2+}$ were defined as the negative $\log _{10}$ of the molar free $\mathrm{Cu}^{2+}$ and $\mathrm{Cd}^{2+}$ ion concentrations (Table 1 ). Cation activities of $\mathrm{Cu}^{2+}$ and $\mathrm{Cd}^{2+}$ were calculated and found below $10^{-11} \mathrm{M}$ in the control conditions.

\subsection{A. catenella growth kinetics}

Growth kinetics of contaminated and control cultures were monitored by counting cells present in $1 \mathrm{~mL}$-Lugol fixed subsamples, with an inverted microscope (Leica DMI 4000 B) at a magnification of $100 \times$. Cell counts were performed until the stationary phase, i.e. during $30 \mathrm{~d}$, at $5 \mathrm{~d}$ period interval. The net growth rate $(\mu)$ and cell doubling rate $(K)$, were then calculated using an exponential model (Landry and Hassett, 1982).

At a given metal concentration, decrease in cell concentration $(\Delta D)$ was calculated by the following equation:

$\Delta D=\frac{D_{T}-D_{M}}{D_{T}} \times 100$

where $D_{T}$ is the cell concentration in control conditions during stationary phase, and $D_{M}$, the cell concentration in given metal contamination conditions during the stationary phase.

Table 1

Total and free metal concentrations, expressed in $\mathrm{M}$, and free metal concentration expressed in $\mathrm{pM}^{2+}$ units, used for $\mathrm{Cu}$ and $\mathrm{Cd}$ contamination of Alexandrium catenella ACT03 cultures.

\begin{tabular}{rllll}
\hline \multicolumn{1}{c}{$[\mathrm{M}] \mathrm{T}(\mathrm{M})$} & {$\left[\mathrm{Cd}^{2+}\right](\mathrm{M})$} & $\mathrm{pCd}^{2+}$ & {$\left[\mathrm{Cu}^{2+}\right](\mathrm{M})$} & $\mathrm{pCu}^{2+}$ \\
\hline $3 \times 10^{-6}$ & $1.30 \times 10^{-8}$ & 7.88 & $9.93 \times 10^{-10}$ & 9.00 \\
$6 \times 10^{-6}$ & $2.59 \times 10^{-8}$ & 7.58 & $2.51 \times 10^{-9}$ & 8.60 \\
$12 \times 10^{-6}$ & $5.19 \times 10^{-8}$ & 7.28 & $7.06 \times 10^{-9}$ & 8.15 \\
$16 \times 10^{-6}$ & $6.93 \times 10^{-8}$ & 7.15 & $1.08 \times 10^{-8}$ & 7.96 \\
$18 \times 10^{-6}$ & $7.80 \times 10^{-8}$ & 7.10 & $1.27 \times 10^{-8}$ & 7.89 \\
$25 \times 10^{-6}$ & $1.08 \times 10^{-7}$ & 6.96 & $1.98 \times 10^{-8}$ & 7.70 \\
$60 \times 10^{-6}$ & $2.92 \times 10^{-7}$ & 6.53 & $5.69 \times 10^{-8}$ & 7.24 \\
$100 \times 10^{-6}$ & $4.38 \times 10^{-7}$ & 6.36 & $1.00 \times 10^{-7}$ & 7.00 \\
\hline
\end{tabular}




\subsection{DOC determination}

The DOC concentrations were measured on $35 \mathrm{~mL}$ A. catenella subsamples, first homogenized, and then filtered through a precombusted $\left(450^{\circ} \mathrm{C}, 4 \mathrm{~h}\right)$ glass fiber filter (Whatman GF/F). In the obtained filtrates, DOC concentrations were determined with a total organic carbon analyzer (TOC- $\mathrm{V}_{\mathrm{CSH}}$, Shimadzu) linked to an automatic sample injector (ASI-V, Shimadzu). DOC measurements were carried out in triplicate, standard deviations being always below $2 \%$. The relative carbon content by cell was obtained by dividing the DOC content by the cell concentration DOC/Cell (ng C Cell ${ }^{-1}$ ), to express the cell activity.

\subsection{D-fluorescence spectroscopy}

The EEMs measurements were carried out in $4 \mathrm{~mL}$ of filtered $A$. catenella subsamples. Fluorescence was measured using a spectrofluorometer (Hitachi F4500) equipped with a Xenon excitation lamp (Xc152HUS, Ushio). The slits of both excitation and emission were fixed at $5 \mathrm{~min}$. The excitation wavelengths were scanned from $200 \mathrm{~nm}$ to $480 \mathrm{~nm}$, and those of the emission were between $200 \mathrm{~nm}$ and $600 \mathrm{~nm}$, both with a $5 \mathrm{~nm}$ step and a scan speed of $2400 \mathrm{~nm} \mathrm{~min}{ }^{-1}$. PARAFAC was programmed based on the software MATLAB (version 6.5) and algorithm of Stedmon (Stedmon and Bro, 2008). The inner filter effect was systematically corrected by the CDA procedure (Luciani et al., 2009) by measuring the raw filtered sample and the half diluted one. After these corrections, the best decomposition of the 96 EEMs $(6 \mathrm{~d} \times 2$ metals $\times 8$ concentrations of metal) was optimized for four components (Concordia: $84.51 \%$ ). Contribution of the components were divided by the DOC concentration to give the specific fluorescence, called $\mathrm{F}_{\mathrm{DOC}}$, or divided by the number of cells in solution to have cell specific fluorescence contribution, called $F_{\text {Cell }}$.

\subsection{Statistical analyses}

Statistical tests were performed using Statistica 7.1. software for Windows. The non-parametric Wilcoxon test was applied to compare growth kinetics among contaminated and control cultures of $A$. catenella. Differences, characterized by $p$ coefficients, were considered as significant at $p<0.05$.

\section{Results}

\subsection{Effects of metals on A. catenella growth kinetics}

Growth of the metal contaminated cultures showed quantitative perturbations in comparison with the control (Fig. 3). For low $\mathrm{Cu}^{2+}$ concentration, $\Delta D$ was decreased from $7 \%$ at $\mathrm{pCu}^{2+}=9.00\left(\mathrm{Cu}_{3}\right)$ to $38 \%$ at $\mathrm{pCu}^{2+}=8.15\left(\mathrm{Cu}_{12}\right)$ (Fig. 1). At higher concentrations, beyond $\mathrm{pCu}^{2+}=7.96\left(\mathrm{Cu}_{16}\right), \Delta D$ decreased drastically (100\%), indicating that no growth was observed. For $C d, \Delta D$ was about $30 \%$ at $\mathrm{pCd}^{2+}=7.88\left(\mathrm{Cd}_{3}\right)$. Concentration of free metals reaching around $1.30 \times 10^{-8} \mathrm{M}$ induced $100 \%$ of decrease in cell concentration for $\mathrm{Cu}_{18}$ and $30 \%$ for $\mathrm{Cd}_{3}$. These results suggest that $\mathrm{Cu}$ was more toxic for $A$. catenella than $\mathrm{Cd}$, at equal concentration in free ions. Between $\mathrm{pCd}^{2+}=7.88$ and $7.28, \Delta D$ increased slightly to $40 \%$, and then more so until $\mathrm{pCd}^{2+}=6.36$, where no growth was observed.

The net growth rate ( $\mu$, Fig. 2$)$ and the doubling rate $(K$, data not shown) of cells in control cultures, reached 0.24 and $0.34 \mathrm{~d}^{-1}$, respectively. For $\mathrm{Cu}$ contamination, beyond $\mathrm{pCu}^{2+}=7.96\left(\mathrm{Cu}_{16}\right)$, the growth of $A$. catenella was totally inhibited $(\mu$ and $\left.K=0.00 \mathrm{~d}^{-1}\right)$. For $\mathrm{Cd}$ contamination, between $\mathrm{pCd}^{2+}=7.88$ and $\mathrm{pCd}^{2+}=7.28$, the $A$. catenella growth seemed to be slightly

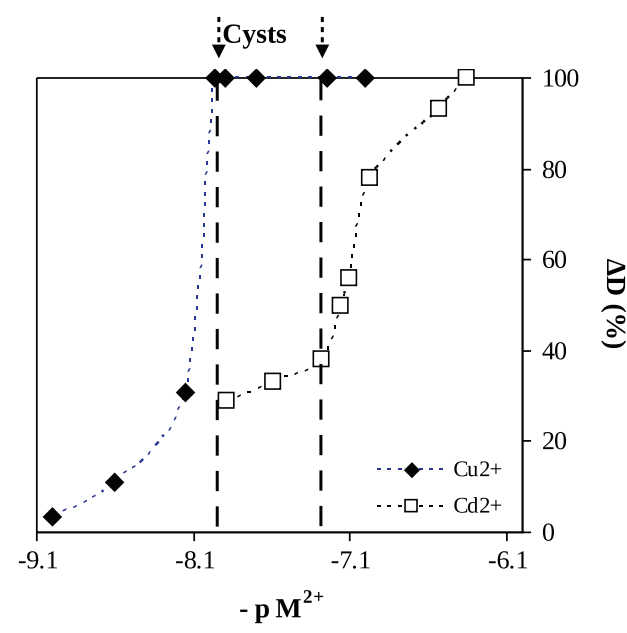

Fig. 1. Decrease in cell concentration of Alexandrium catenella ACT03 at the stationary phase of growth (>day 20 ) under $\mathrm{Cu}$ or $\mathrm{Cd}$ contamination. $\Delta D$ : decrease in cell concentration.

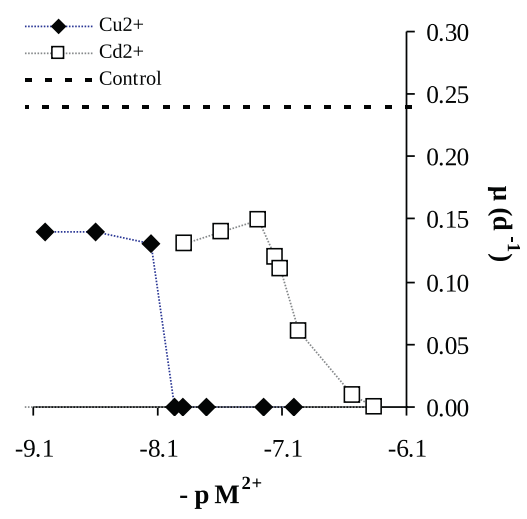

Fig. 2. Net growth rates $\left(\mu\right.$, in $\left.\mathrm{d}^{-1}\right)$ of Alexandrium catenella ACT03 in control and metal contaminated cultures.

enhanced, as attested by the increase in $\mu\left(0.13-0.15 \mathrm{~d}^{-1}\right)$ and in $K\left(0.18-0.21 \mathrm{~d}^{-1}\right)$. Then, a regular decrease in the $\mu$ values was observed from $\mathrm{pCd}^{2+}=7.15\left(0.12 \mathrm{~d}^{-1}\right)$ to $\mathrm{pCd}^{2+}=6.36\left(0.00 \mathrm{~d}^{-1}\right)$.

\subsection{Effects of metals on DOC/Cell release}

The DOC/Cell released was systematically observed at day 5 , suggesting a fast cell reaction towards metal stress (Fig. 4 ). The cultures contaminated by $\mathrm{pCu}^{2+}=9.00$ and $\mathrm{pCu}^{2+}=8.60$, exhibited no significant difference in DOC/Cell (Wilcoxon test: $p>0.05$ ) compared to control. However, the contamination at $\mathrm{pCu}^{2+}=7.96$ $\left(\mathrm{Cu}_{16}\right)$ showed significantly higher DOC/Cell (3.3-27.0 ng Cell $\left.{ }^{-1}\right)$ than the control (Wilcoxon test: $p<0.05$ ) (Fig. 4A). This increase was persistent until $\mathrm{pCu}^{2+}=7.89\left(\mathrm{Cu}_{18}\right)$. For Cd contamination, it seemed that DOC/Cell was enhanced under higher contamination levels (Fig. 4B), but in a lesser value than that obtained in presence of copper. For both $\mathrm{Cu}$ and $\mathrm{Cd}$, the cellular exudation carbon ratio showed a depression on day 10. The maximal values of DOC/Cell were observed at $\mathrm{pCu}^{2+}=7.96$ and at $\mathrm{pCd}^{2+}=6.36$.

\subsection{Effects of metals on FDOM}

The $\mathrm{C} 1$ component (Figs. 5-7, Line 1 ) had a maximum intensity for $240 \mathrm{~nm}$ of excitation and $350 \mathrm{~nm}$ of emission, with a slow decrease until $420 \mathrm{~nm}$. This component combined a tryptophan peak (SR peak maximum around $340 \mathrm{~nm}$, in Burdige et al., 2004), and 

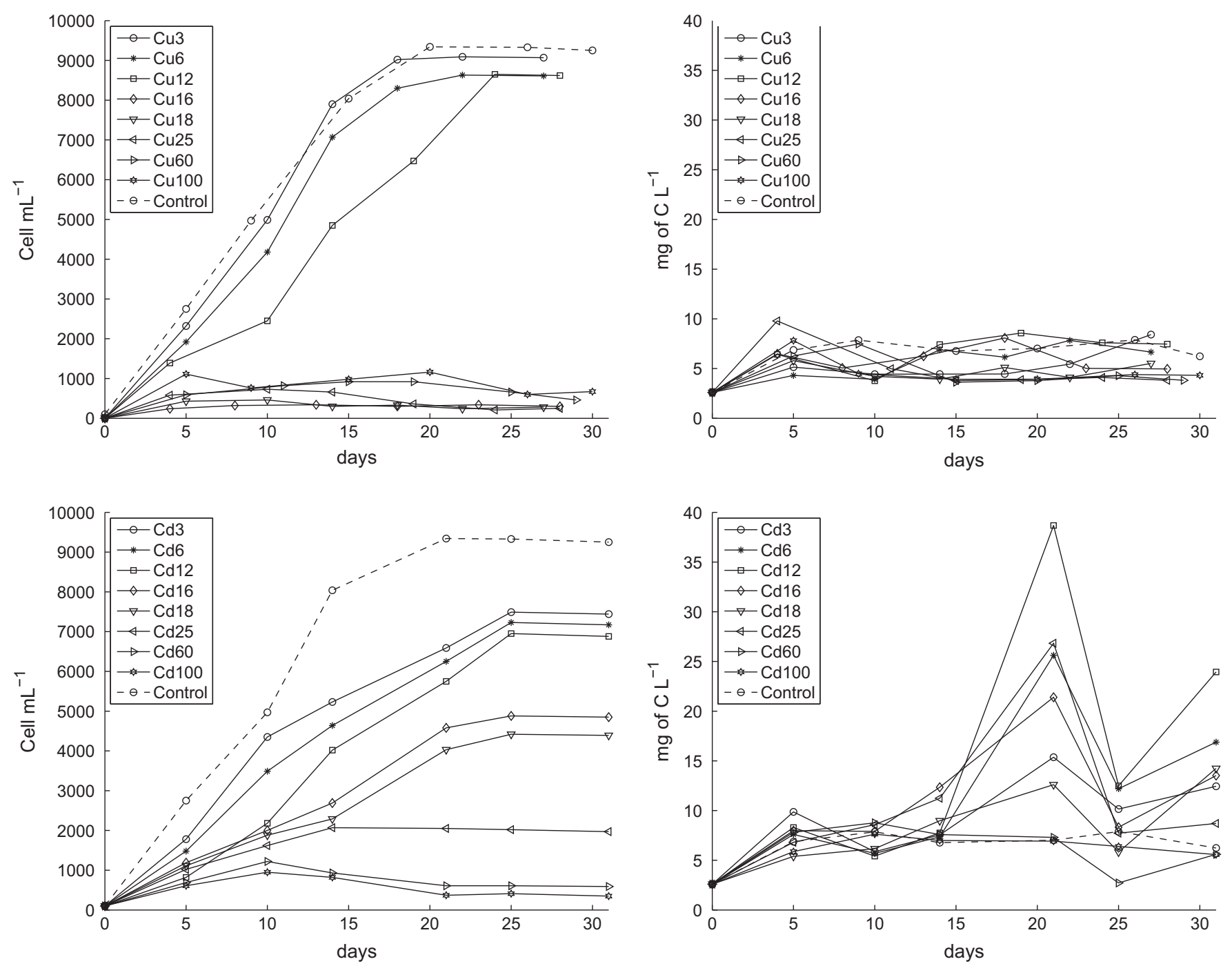

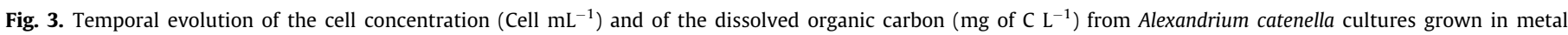

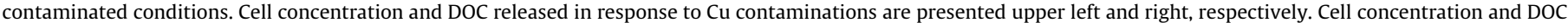

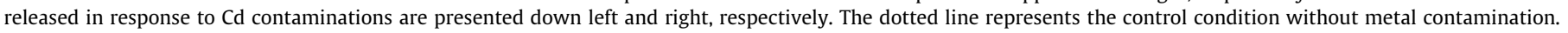
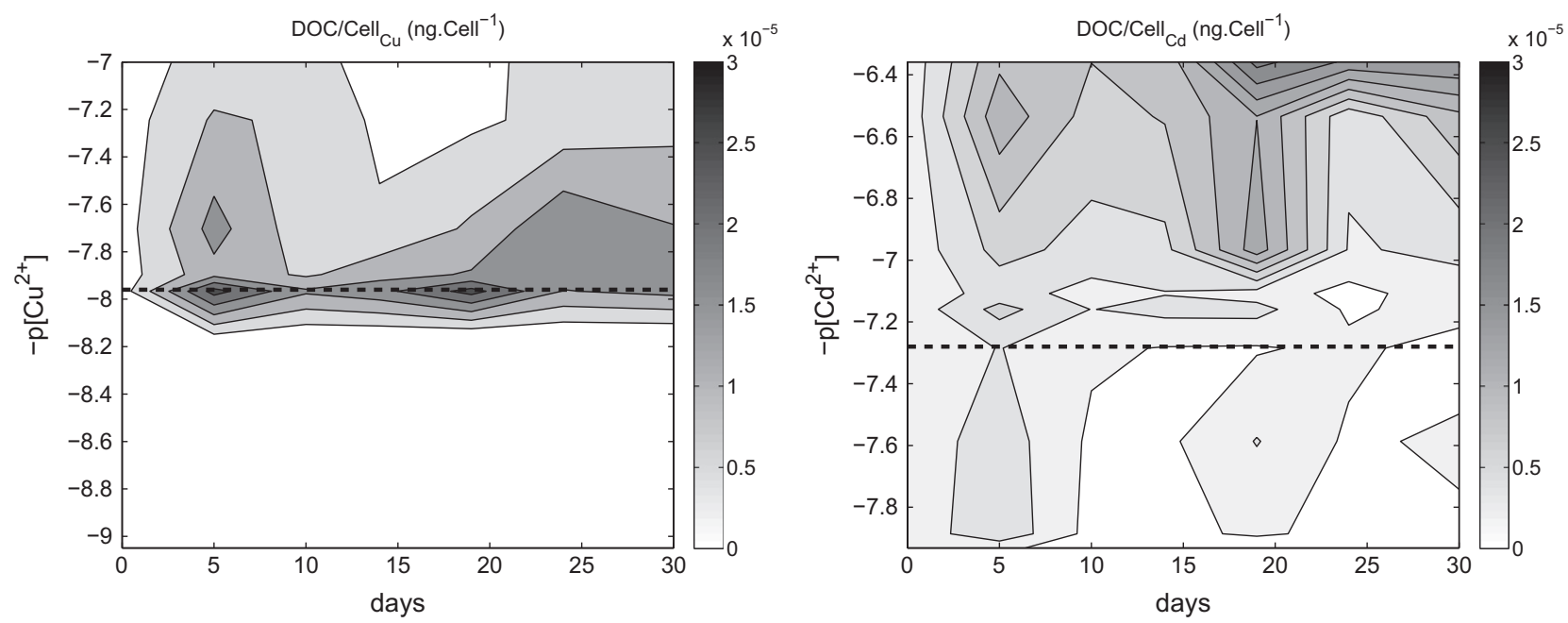

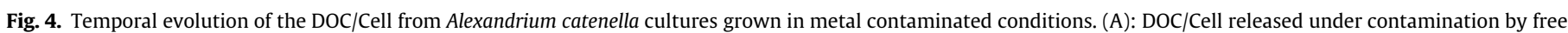
$\mathrm{Cu}(\mathrm{B})$ : DOC/Cell released under contamination by free $\mathrm{Cd}$. The dotted line represents the cyst apparition and control conditions are represented by the $x$ axis. 

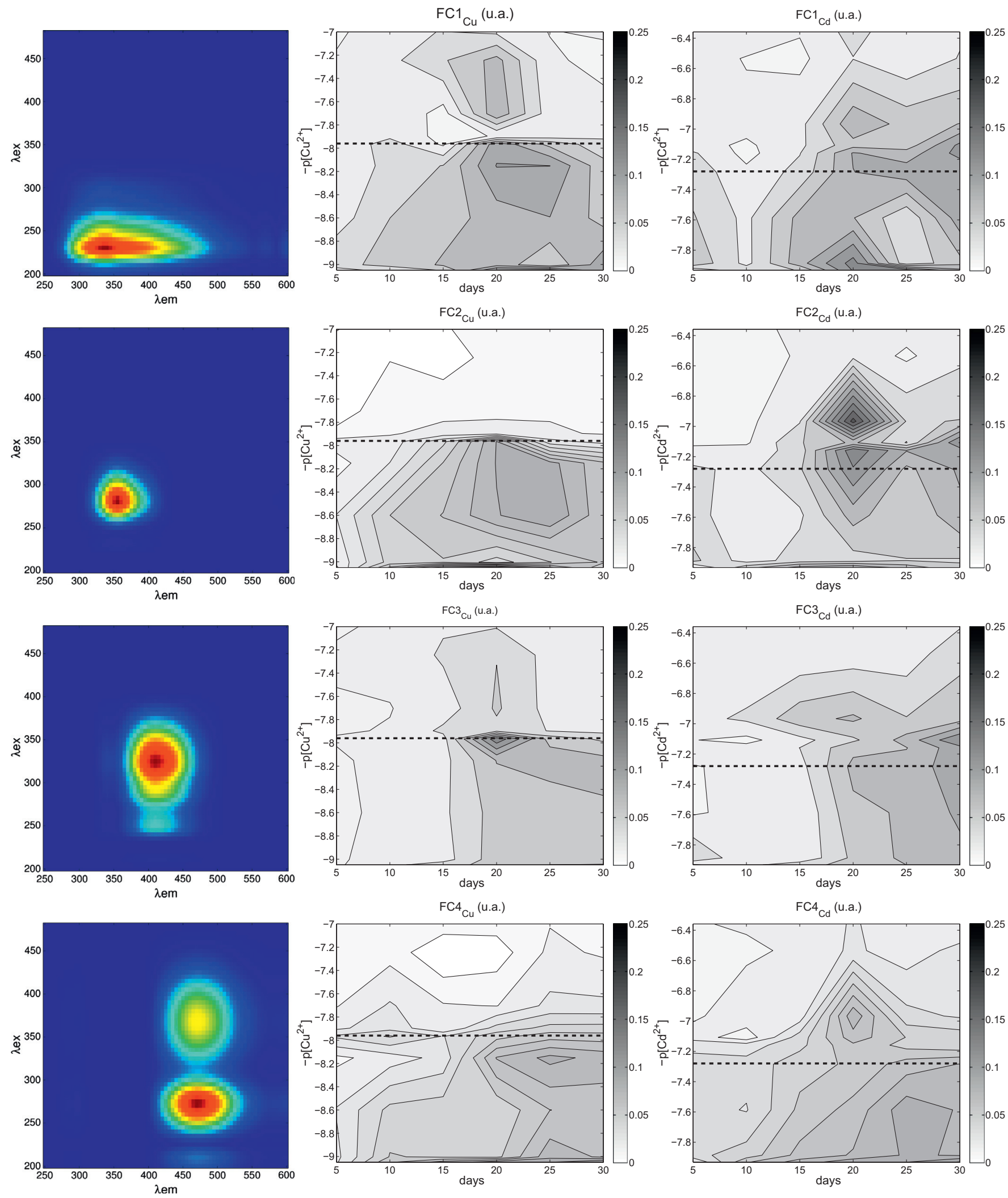

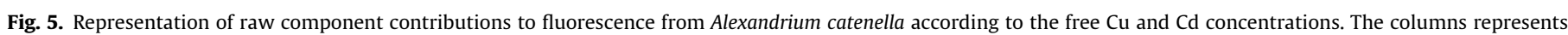

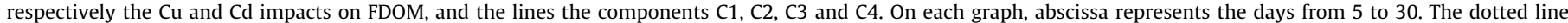
represents the cyst apparition.

characteristics of a humic/fulvic substances peak (Coble, 1996; Patel-Sorrentino et al., 2002). It therefore represented a domain gathering the fluorescent protein substances excitation wavelengths, associated with the humic substances. 

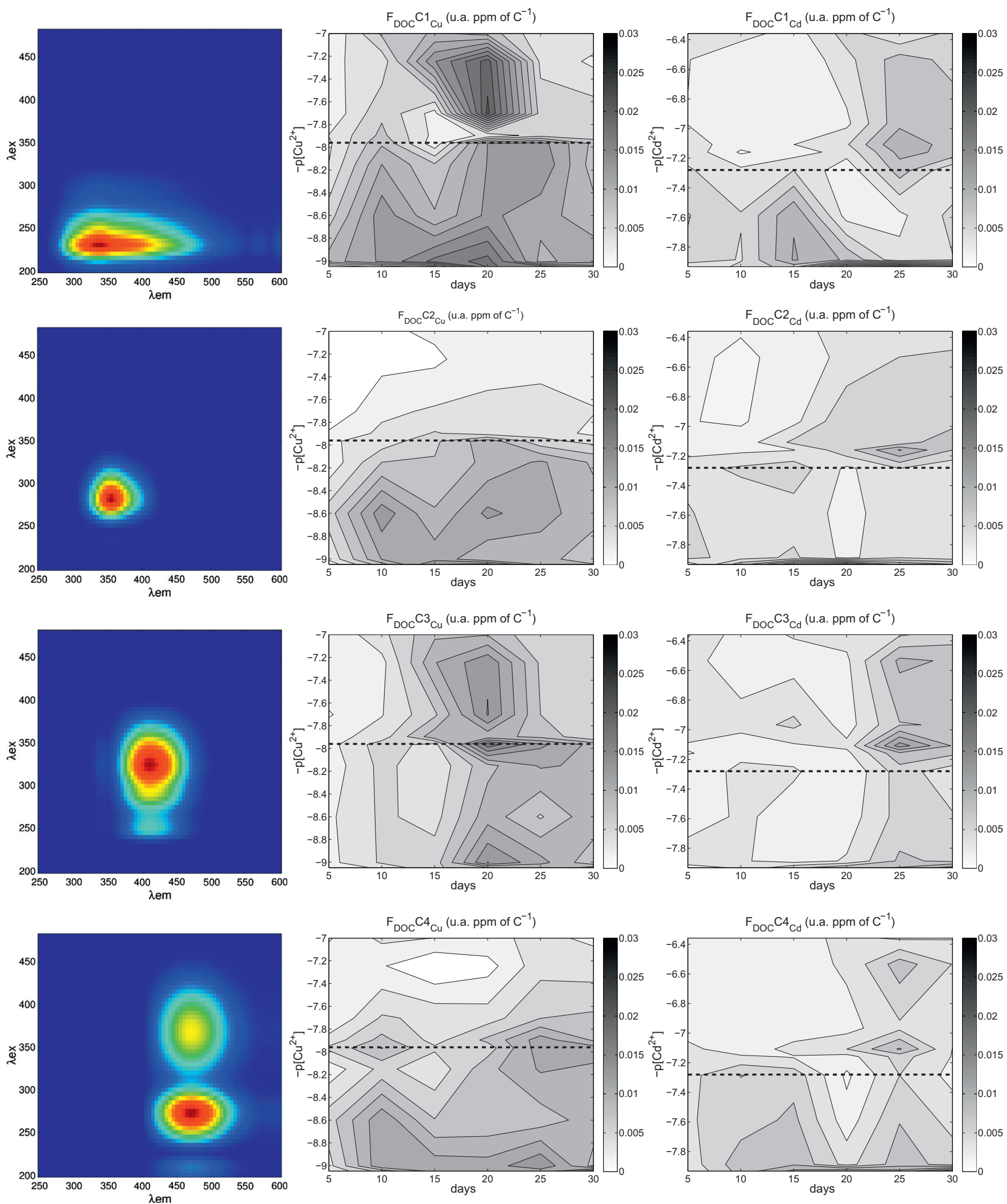

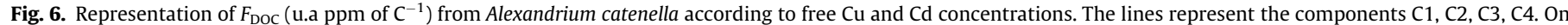
each graph, abscissa represent the days from 5 to 30 . The dotted line represents the cyst apparition.

The C2 component (Figs. 5-7, Line 2) was located between 250 and $315 \mathrm{~nm}$ for excitation and between 315 and $400 \mathrm{~nm}$ for emission. Indeed, the maximum of the peak was positioned at the couple of wavelengths EX/EM $=280 / 355 \mathrm{~nm}$. This component was considered as a fluorescent protein fluorophore tryptophan (type T). 

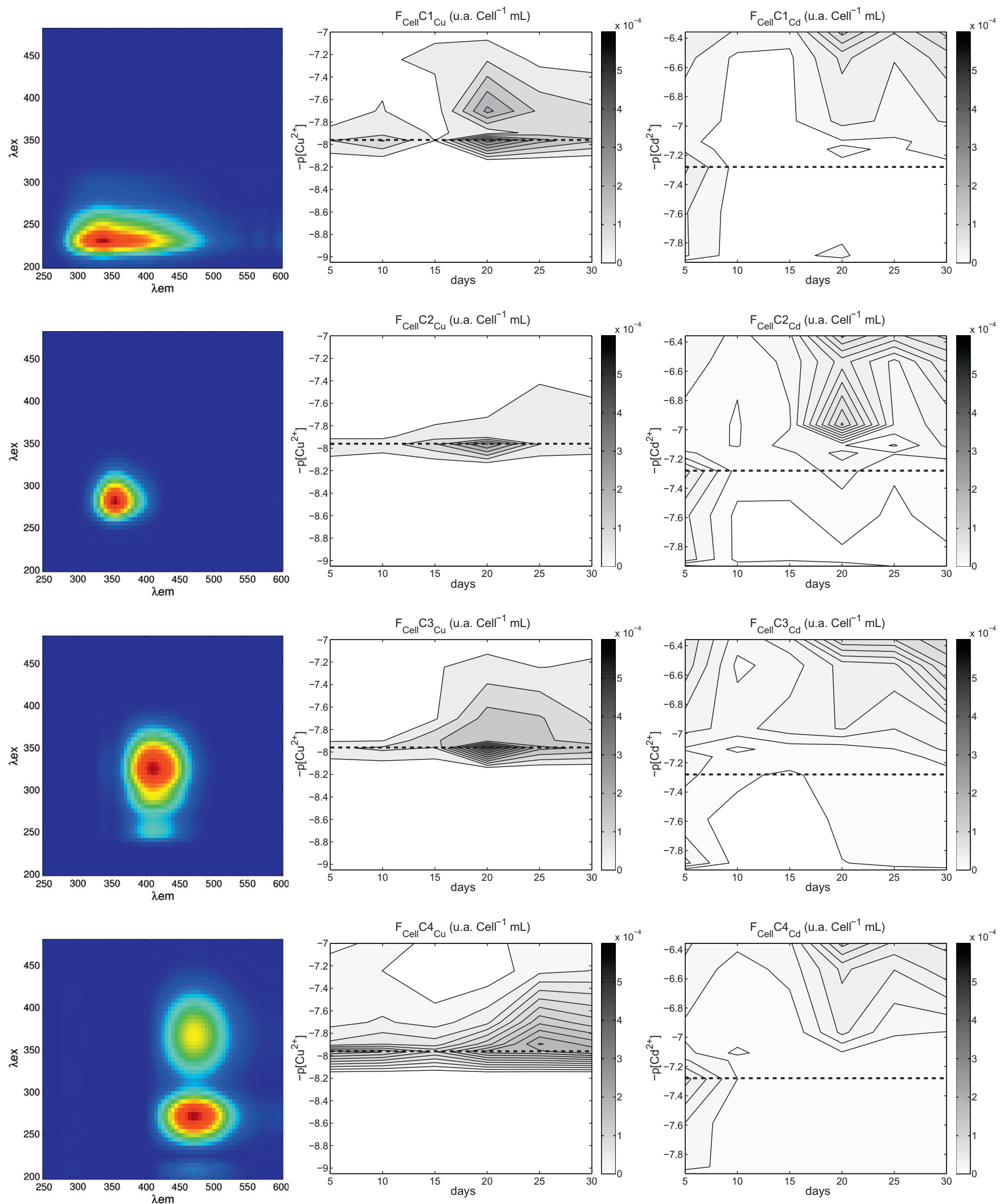

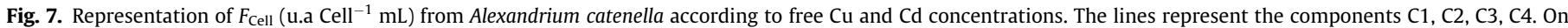
each graph, abscissa represent the days from 5 to 30. The dotted line represents the cyst apparition and control conditions are represented by the $x$ axis.

The C3 component (Figs. 5-7, Line 3) was positioned around $325 \mathrm{~nm}$ for excitation and $415 \mathrm{~nm}$ for emission. This component was related to humic fluorophores in environmental waters.
According to Coble (1996), the existence of this fluorophore is linked to the marine environment (type $\mathrm{C}$ ) and is widespread during the marine production (Ishii and Boyer, 2012). 
The C4 component (Figs. 5-7, Line 4) contained two well defined peaks. The less pronounced peak was located in the high excitation wavelength, at $370 \mathrm{~nm}$, while the major one was excited between 275 and $460 \mathrm{~nm}$. The maximal intensities were associated to the same emission wavelength, at $460 \mathrm{~nm}$. The nearest component described in literature by Coble (1996) is the component generally associated with humic terrestrial inputs (types $\mathrm{A}$ and $\mathrm{C}$ ).

\subsubsection{Control condition}

In the control cultures, all the fluorescence components showed an increase in the fluorescence contribution, from day 5 to day 15 (Fig. 5). For C1 component, an important increase was observed after day 15 , followed by maxima on days 20 and 25, and decrease on day 30. For C2 component, the increase from day 15 to 20 was softer, with a regular decrease from day 20 to day 30 . However, the C3 and C4 components accused a linear contribution according to the days, until the end of experiment. Hence, without metal addition, the FDOM production seemed to be maximal between days 20-25 and 15-20, for C1 and C2 components, respectively. As these components were linked to proteins, these could be indicators of the low biological activity during the stationary phase. The regular increase in the $\mathrm{C} 3$ and $\mathrm{C} 4$ components indicated the production of more aromatic and complex components among the FDOM.

\subsubsection{Contamination with copper}

For $\mathrm{Cu}$ contamination, the fluorescence contribution was generally lower than for the control (Fig. 5). For C1, C2 and C3 components, the fluorescence contribution increased until the cyst development, defined as the $\mathrm{Cu}^{2+}$ concentration: $\mathrm{pCu}^{2+}=7.96$. Beyond this value, the contribution to fluorescence was drastically decreased. Hence, one can consider that the decrease in fluorescence with increasing metal concentrations was more related to low biological production rather than to the metal quenching. Except for C4 component, the maximum of contribution occurred on day 20. The fluorescent signal appeared under moderate $\mathrm{pCu}^{2+}$ (8.15-8.60). For the C3 and C4 components, a regular increase in the contribution to fluorescence was observed until the cyst apparition defined above. These components seemed to be less affected by metal contamination, except for the last days of growth (days 20,25 and 30), where the contribution decreased. The contribution of $\mathrm{C} 4$ component decreased with $\mathrm{pCu}^{2+}$, keeping linear trend during the experiments, except on day 25 , before the cyst apparition.

The specific contribution $\left(F_{\mathrm{DOC}}\right)$, for $\mathrm{C} 1$ component, decreased between low (9.00) and high $\mathrm{pCu}^{2+}(8.15)$ (Fig. 6). For the $\mathrm{C} 2 \mathrm{com}-$ ponent, the $\mathrm{F}_{\mathrm{DOC}}$, which increased until day 10 , and decreased on day 15 , appeared for $\mathrm{pCu}^{2+}$ comprised between 8.60 and 8.15 . The $F_{\mathrm{DOC}}$ of the $\mathrm{C} 3$ component did not change in trend, like $\mathrm{C} 4 \mathrm{com}$ ponent, compared to control.

The highest $\mathrm{F}_{\text {Cell }}$ were observed with a lesser importance for $\mathrm{C} 1$, $\mathrm{C} 2$ and $\mathrm{C} 3$ components, at $\mathrm{pCu}^{2+}=7.96$ (Fig. 7), where cysts appeared. Based on these observations, the maximum of specific fluorescence was hence observed when the cells transformed into resistance cysts.

\subsubsection{Contamination with cadmium}

For $\mathrm{Cd}$, like for $\mathrm{Cu}$, the maximum fluorescence contribution occurred on day 20, with an increased until $\mathrm{pCd}^{2+}=7.15$ (Fig. 5). This behavior was more intense for $\mathrm{C} 2$ component. Furthermore, the highest fluorescence contributions were obtained for the $\mathrm{C} 1 \mathrm{com}-$ ponent, represented by low concentration $\left(\mathrm{pCd}^{2+}=7.88\right)$, and the C2 component, represented by medium concentrations $\left(\mathrm{pCd}^{2+}=7.10-7.15\right)$. However, the C3 and C4 components showed a regular increase until the end of incubation, with a similar peak in intensity at day 20.

For $F_{\mathrm{DOC}}$, the maximum was observed on day 25 (instead 20 observed for $\mathrm{Cu}$ conditions) (Fig. 6). A maximum plateau was observed during the last incubation period (days 20, 25 and 30), when free concentration was above the cyst apparition, defined as the $\mathrm{Cd}^{2+}$ concentration: $\mathrm{pCd}^{2+}=7.28$. Otherwise, like $\mathrm{Cu}$, one can observe that specific contribution was quite constant in function of $\mathrm{Cd}^{2+}$, except beyond $\mathrm{pCd}^{2+}=6.96$, where there was the plateau. This pointed out a difference between $\mathrm{Cu}$ and $\mathrm{Cd}$ effects. However, specific fluorescence contribution by cell $\left(F_{\text {Cell }}\right)$ was less important than for $\mathrm{Cu}$ contamination at the same free concentration (Fig. 7). It exhibited an increase after the cyst apparition, and kept a maximum after the exponential phase, on day 20, visible at high concentrations. The maximum of $F_{\text {Cell }}$ was observed just before, at $\mathrm{pCd}^{2+}=6.36$, where no growth was observed.

\subsubsection{Comparison of the contaminant effects of copper and cadmium}

For both metals, fluorescent contribution for the C3 and C4 components showed a regular increase during the growth, and a regular decrease with the metal concentration (Fig. 5). $\mathrm{Cu}$ and $\mathrm{Cd}$ had different effects on FDOM release. The C3 component was less affected by $\mathrm{Cd}^{2+}$ and $\mathrm{Cu}^{2+}$ than by the growth phase, as this component was linked to humic marine matter. By contrast, the C4 component was the most affected component, since its contribution decreased with the increasing metal concentrations.

The $F_{\mathrm{DOc}}$ according to the different $\mathrm{Cu}$ levels, observed at day 20 , was enhanced in presence of low free concentrations, from $9.93 \times 10^{-10}$ to $7.06 \times 10^{-9} \mathrm{M}$, whereas, for $\mathrm{Cd}$, the trend was less observable due to the low values of $F_{D O c}$. The FDOM, described by $\mathrm{C} 1$ and $\mathrm{C} 2$ components, defined the protein domains (Fig. 6), and was thus in relation with the biological activity. Hence, when $\mathrm{Cu}^{2+}$ and $\mathrm{Cd}^{2+}$ levels were beyond the cyst apparitions, the cells were not able to produce fluorescent extracellular molecules. The FDOM defined by humic fluorophores, could result from cellular debris, or encystment phenomenon.

\section{Discussion}

\subsection{Growth of A. catenella and DOC/Cell release}

The growth of $A$. catenella in $\mathrm{f} / 2$ culture medium followed a similar pattern to that described for other dinoflagellate species (Juhl, 2005). Reduction of the A. catenella growth after metal contamination, recorded in this study, was in agreement with previous studies conducted on other dinoflagellates (Lage et al., 1994). Here, we have expressed the decrease in cell concentration through some variables such as the net growth rate $(\mu)$ and the specific doubling rate $(K)$ (Landry and Hassett, 1982). Net growth rate $(\mu)$ is the most prevalent endpoint used in toxicity tests, since any toxic effect may be reflected in cell growth change (Miao et al., 2005). A previous study reported a maximal net growth rate of $0.89 \mathrm{~d}^{-1}$ for A. catenella during a bloom of this species in the Angle creek of Thau lagoon (southern France) (Collos et al., 2007). This rate, mentioned for the species grown in situ, was 3 times higher than that we have registered in control cultures $\left(0.24 \mathrm{~d}^{-1}\right)$. However, our values were similar to those found by others authors reporting a net growth rate of $0.29 \mathrm{~d}^{-1}$ for $A$. catenella at an optimal temperature of $20^{\circ} \mathrm{C}$, for a light-dark cycle of $14 \mathrm{~h}: 10 \mathrm{~h}$ (Siu et al., 1997). In contaminated conditions, for the present study, A. catenella exhibited contrasting net growth rates according to the metal contamination. In response to the first addition of $\mathrm{Cu}$ or $\mathrm{Cd}$, the growth rates showed lower values around $0.14 \mathrm{~d}^{-1}$, compared to the control $\left(0.24 \mathrm{~d}^{-1}\right)$. These values were lower than those obtained for Gymnodinium sp. contaminated by 0.2 and $0.5 \mathrm{mg} \mathrm{L}^{-1}$ of $\mathrm{Cu}$, which were of the order of 0.33 and $0.34 \mathrm{~d}^{-1}$ respectively, compared to the control $\left(0.54 \mathrm{~d}^{-1}\right)$ (Pistocchi et al., 1997). In contrast, for similar metal concentrations, higher growth rates $\left(0.92-0.46 \mathrm{~d}^{-1}\right)$ have been found for Cylindrotheca fusiformis (Pistocchi et al., 1997). On the other 
hand, for Amphidinium carterae, the growth rate was affected in a more acute way at low concentration of Cu (Lage et al., 1994). These observations suggest that dinoflagellate growth could be more sensitive to metals than diatom growth.

In the present study, for copper contamination, the values of $\mu$ and $K$ have dropped suddenly to zero just after $\mathrm{pCu}^{2+}=7.96$, meaning a drastic toxic effect on $A$. catenella. For cadmium contamination, the decrease in $\mu$ and $K$ values was slower, from $\mathrm{pCd}^{2+}=7.15$ to $\mathrm{pCd}^{2+}=6.36$ where values became null. This suggests different toxic effects on the species, between copper and cadmium. The contaminant effects of these metals on FDOM and DOC, at low free concentrations, differed, indicating different mechanisms of adaptation to the presence of toxic ions. The $\Delta D$ was about $30 \%$ for the ion free activity concerning $\mathrm{Cd}$ $\left(\mathrm{pCd}^{2+}=7.88\right)$ or $\mathrm{Cu}\left(\mathrm{pCu}^{2+}=8.15\right)$. This may indicate the resistance of the cells at these low free metal concentrations in the medium. Free $\mathrm{Cu}$ concentrations up to $\mathrm{pCu}^{2+}=8.60$, acted slightly on the growth of $A$. catenella. However, the effect of $\mathrm{Cu}^{2+}$ was evident for concentrations higher than $\mathrm{pCu}^{2+}=8.15$, since $A$. catenella cells transformed into cysts. Similar results have been found in other studies for A. carterae and Prorocentrum micans exposed to total $\mathrm{Cu}$ concentration of $7.87 \mu \mathrm{M}(1.94 \mu \mathrm{M}$ labile copper), these species showing inhibition (100\%) or reduction (70\%) of cell motility in these conditions (Lage et al., 1994).

At high metal concentrations, although the growth rates declined, $A$. catenella cells seemed to resist towards $\mathrm{Cu}$ and $\mathrm{Cd}$ stress, and be still able to survive. This resistance was marked by the release of extracellular DOM by cells. The general trend for the DOC released could be explained by an increase in the cell number (Fig. 3), more rapid than the DOC production, leading to a depression of the DOC/Cell pattern during the exponential phase. During the stationary phase (>day 20), the DOC/Cell reached a maximum plateau. The DOC/Cell was maximal for $\mathrm{pCu}^{2+}=7.96$ and $\mathrm{pCd}^{2+}=6.36$, as the cells produced the maximum of DOC, when the free metal toxicity was reached. Cells could release more chelating molecules in the culture medium, in response to the increased metal contamination. These mechanisms seemed to function even when total inhibition was reached, independently of the cyst development.

DOC exudated by the cells showed increases according to free metal concentrations. This trend could be consistent with tendency of cells to protect themselves against damages that could affect cell metabolism, by producing more DOC. It has already been shown that anionic polysaccharides, able to bind metal ions, are released by some phytoplankton species to protect cells from metals (Kaplan et al., 1987). The latter study was in accordance with the increased values of DOC/Cell released by A. catenella in response to metal stress, found in our study.

\subsection{Fluorescence}

The observed fluorescence exhibited variations according to the free metal concentrations and to the incubation time. The contribution of fluorescence of each component (C1, C2, C3 and C4), for the two metal studied, was dependent on the growth, the free metal activity, or the two at the same time. The results here presented, showed an enhancement of fluorescence during the incubation period. This increase in fluorescence was synchronized with exponential growth of cells for the $\mathrm{C} 1$ and $\mathrm{C} 2$ components, and showed a linear increase slightly perturbed by metal, for the C3 and C4 components. For this reason, two hypotheses can be considered. The first one supposed that $F_{\text {Cell }}$ should be constant, during the incubation of the cultures in the presence of metals, even if the free metal concentrations increased. This was not the case, particularly for high $\mathrm{Cu}^{2+}$ levels. Moreover, the $F_{\mathrm{DOC}}$ has increased with the increasing in cell numbers, meaning that the DOC release was related to the phytoplankton concentration. This suggests that the fluorescence was more related to the extracellular carbon exudates by cells. The second hypothesis suggested that the fluorescent substances released by cells were linked to free metals, meaning that concentrations of $\mathrm{Cu}^{2+}$ under the cyst apparition, activated mechanisms that produced fluorescent substances in the medium. However, at concentration of $10^{-8} \mathrm{M}$ for $\mathrm{Cu}^{2+}$ and $10^{-7} \mathrm{M}$ for $\mathrm{Cd}^{2+}$, cells were transformed into cysts; therefore, the fluorescence could come from cyst formation or from cell degradation. The variation of fluorescence was expressed through the C3 and $\mathrm{C} 4$ components, indicated that the specific contribution increased with time (more dead cells during stationary phase, and with the free metal concentrations). These fluorophores were typical of marine humic-like material (Parlanti et al., 2000) and their appearance is a sign of degradation of organic matter. Furthermore, the fluorophore responsible of these two components have already been recognized as typical humic-like components receiving individual designation, like A and C (Coble, 1996; Patel-Sorrentino et al., 2002). The C3 and C4 components were continuously produced during the growth, and were associated with DOC, suggesting their important relationships to the marine production of fresh organic matter, rather than to terrestrial signal (Coble, 1996). The biological origin of this fluorescence contribution was supported by the fact that the net production (DOC) was affected by the metal quenching. Indeed, the more the free metal concentration increased, the less the contribution was important. Besides, the maximal level of specific DOC/Cell was synchronized with this fluorescence contribution, which occurred during the exponential growth phase. This indicated that these components occurred at the same time that the defense mechanisms against metal stress.

The presence of the $\mathrm{C} 1$ and $\mathrm{C} 2$ components may indicate the excretion of dissolved protein and their protein by-products (amino acids for example). The fluorescence of proteins was generally observed when free metal levels were below the critical values, specific for each metal, reaching $5.19 \times 10^{-8}$ and $1.08 \times 10^{-8} \mathrm{M}$ for $\mathrm{Cd}^{2+}$ and $\mathrm{Cu}^{2+}$, respectively. Below these values, the cells overcame the quenching effect due to $\mathrm{Cu}$ and $\mathrm{Cd}$, and produced fluorescent components.

The $\mathrm{C} 1$ and $\mathrm{C} 2$ components were also used as markers, to estimate biological activity and different stages of the biological production, as it has been shown by previous studies (Parlanti et al., 2000). Indeed, the $C 1$ component seemed to be more related to the defense mechanisms of cells, while the C2 component appeared more linked to the growth process of the species. Chlorophyll- $a$ degradation product could not be responsible for this signal, since their fluorescence maxima were situated above $650 \mathrm{~nm}$ (French, 1960).

\section{Conclusions}

The main objective of this study was to determine, for the first time, the characterization of exudates from the toxic dinoflagellate A. catenella grown in metal contaminated medium. Results revealed that under metal stress conditions, the development of $A$. catenella was perturbed from the ion free concentration of: $10^{-8} \mathrm{M}$ for $\mathrm{Cu}$ and $10^{-7} \mathrm{M}$ for $\mathrm{Cd}$.

We report an increase in organic matter exudates by cells under metal stress, at the end of the exponential phase. The release of organic molecules should play an important role in metal speciation. It is concluded that the dynamic release of organic molecules depended on the nature and on the concentration of metals. The metal toxicity induced pronounced release of extracellular material, and led to an inhibition of the net growth.

The FDOM was treated by the PARAFAC and gave 4 usable components. Two components ( $\mathrm{C} 1$ and $\mathrm{C} 2$ ) were related to the 
biological activity involved in growth processes, and defence against stress metal. C1 appeared before and after cyst apparition, while $\mathrm{C} 2$ was involved in low contamination stress conditions. The two others components ( $\mathrm{C} 3$ and $\mathrm{C} 4$ ) were more linked to degradation of organic matter from algal cells. These components were more sensitive to metal quenching during growth process. The fluorescence quantum yield of the released carbon, decreased according to metal concentrations, it was high under low metal concentrations, but declined with increasing metal levels. This observation is consistent with the production of less fluorescent DOC, suggesting the predominance of polysaccharides instead of proteins in the exudated molecules.

\section{Acknowledgments}

This research was supported by the Conseil Général du Var (CG), Toulon Provence Méditerranée (TPM) and ARCUS CERES project (Région PACA-MAE). We are deeply indebted to Yves COLLOS and Estelle MASSERET from the Laboratory ECOSYM UMR 5119 of the Montpellier 2 University, for providing us with the A. catenella strain ACT03 used in the study.

\section{References}

Banaitis, M.R., Waldrip-Dail, H., Diehl, M.S., Holmes, B.C., Hunt, J.F., Lynch, R.P., Ohno, T., 2006. Investigating sorption-driven dissolved organic matter fractionation by multidimensional fluorescence spectroscopy and PARAFAC. J. Colloid Interf. Sci. 304, 271-276.

Bro, R., Kiers, H.A.L., 2003. A new efficient method for determining the number of components in PARAFAC models. J. Chemometr. 17, 274-286.

Bro, R., 1997. PARAFAC tutorial and applications. Chemometr. Intell. Lab. 38, 149171.

Burdige, D.J., Kline, S.W., Chen, W., 2004. Fluorescent dissolved organic matter in marine sediment pore waters. Mar. Chem. 89, 289-311.

Chan, L.L., Lo, S.C.L., Hodgkiss, I.J., 2002. Proteomic study of a model causative agen of harmful red tide, Prorocentrum triestinum I: optimization of sample preparation methodologies for analyzing with two-dimensional electrophoresis. Proteomics 2, 1169-1186.

Coble, P.G., 1996. Characterization of marine and terrestrial DOM in seawater using excitation-emission matrix spectroscopy. Mar. Chem. 51, 325-346.

Collos, Y., Vaquer, A., Laabir, M., Abadie, E., Laugier, T., Pastoureaud, A., Souchu, P., 2007. Contribution of several nitrogen sources to growth of Alexandrium catenella during blooms in Thau lagoon, southern France. Harmful Algae 6, 781789.

Cordova, J.L., Muller, I., 2002. Use of PCR and partial sequencing of the large-subunit rRNA gene of identify Alexandrium catenella (Dinophyceae) from the south of Chile. Harmful Algae 1, 343-350.

Frehi, H., Couté, A., Mascarell, G., Perrette-Gallet, C., Ayada, M., Kara, M.H., 2007. Dinoflagellés toxiques et/ou responsables de blooms dans la baie d'Annaba (Algérie). C.R. Biologies 330, 615-628.

French, C.S., 1960. The chlorophylls in vivo and in vitro. In: Ruhland, W. (Ed.), Encyclopedia of Plant Physiology. Springer, Berlin, pp. 252-279.

Glibert, P.M., Anderson, D.M., Gentien, P., Graneli, E., Sellner, K.G., 2005. The global complex phenomena of harmful algal blooms. Oceanography 18, 136-147.

Holbrook, R.D., Yen, J.H., Grizzard, T.J., 2006. Characterizing natural organic material from the Occoquan Watershed (Northern Virginia, US) using fluorescence spectroscopy and PARAFAC. Sci. Total Environ. 361, 249-266.

Ishii, S.K.L., Boyer, T.H., 2012. Behavior of reoccurring PARAFAC components in fluorescent dissolved organic matter in natural and engineered systems: a critical review. Environ. Sci. Technol. 46, 2006-2017.

Jaffé, R., Boyer, J.N., Lu, X., Maie, N., Yang, C., Scully, N.M., Mock, S., 2004. Source characterization of dissolved organic matter in a subtropical mangrove dominated estuary by fluorescence analysis. Mar. Chem. 84, 195-210.

Jean, N., Boge, G., Jamet, J.L., Jamet, D., 2006. Comparison of ßdimethylsulfoniopropionate (DMSP) levels in two Mediterranean ecosystems with different trophic levels. Mar. Chem. 101, 190-202.

Jean, N., Boge, G., Jamet, J.L., Richard, S., Jamet, D., 2005. Annual contribution of different plankton size classes to particulate dimethylsulfoniopropionate in a marine perturbed ecosystem. J. Mar. Syst. 53, 235-247.

Juhl, A.R., 2005. Growth rates and elemental composition of Alexandrium monilatum a red-tide dinoflagellate. Harmful Algae 4, 287-295.

Kaplan, D., Christiaen, D., Arad, S., 1987. Chelating properties of extracellular polysaccharides from Chlorella spp.. Appl. Environ. Microb. 53, 2953-2956.
Kowalczuk, P., Ston-Egiert, J., Cooper, W.J., Whitehead, R.F., Durako, M.J., 2005. Characterization of chromophoric dissolved organic matter (CDOM) in the Baltic Sea by excitation emission matrix fluorescence spectroscopy. Mar. Chem. 96, 273-292.

Lage, O.M., Parente, A.M., Soares, H.M.V.M., Vasconcelos, M.T.S.D., Salema, R., 1994. Some effects of copper on the dinoflagellates Amphidinium carterae and Prorocentrum micans in batch cultures. Eur. J. Phycol. 29, 253-260.

Landry, M.R., Hassett, R.P., 1982. Estimating the grazing impact of marine microzooplankton. Mar. Biol. 67, 283-288.

Le Faucheur, S., Behra, R., Sigg, L., 2005. Phytochelatin induction, cadmium accumulation and algal sensitivity to free cadmium ion in Scenedesmus vacuolatus. Environ. Toxicol. Chem. 24, 1731-1737.

Lilly, E.L., Kulis, D.M., Gentien, P., Anderson, D.M., 2002. Paralytic shellfish poisoning toxins in France linked to a human-introduced strain of Alexandrium catenella from western Pacific: evidence from DNA and toxin analysis. J. Plankton Res. 24, 443-452.

Lloyd, J.B.F., 1971. Synchronized excitation of fluorescence emission spectra. Nature $231,64-65$

Luciani, X., Mounier, S., Paraquettti, H.H.M., Redon, R., Lucas, Y., Bois, A., Lacerda, L.D., Raynaud, M., Ripert, M., 2008. Tracing of dissolved organic matter from the SEPETIBA Bay (Brazil) by PARAFAC analysis of total luminescence matrices. Mar. Environ. Res. 65, 148-157.

Luciani, X., Mounier, S., Redon, R., Bois, A., 2009. A simple correction method of inner filter effects affecting FEEM and its application to the PARAFAC decomposition. Chemometr. Intell. Lab. 96, 227-238.

Miao, A.J., Wang, W.X., Juneau, P., 2005. Comparison of Cd, Cu, and $\mathrm{Zn}$ toxic effects of four marine phytoplankton by pulse-amplitude-modulated fluorometry. Environ. Toxicol. Chem. 24, 2603-2611.

Moffett, J.W., Brand, L.E., Zika, R.G., 1990. Distribution and potential sources and sinks of copper chelators in the Sargasso Sea. Deep Sea Res. 37, 27-36.

Mounier, S., Patel, N., Quilici, L., Benaim, J.Y., Benamou, C., 1999. Fluorescence 3D de la matière organique dissoute du fleuve amazone (three-dimensional fluorescence of the dissolved organic carbon in the Amazon river). Water Res. 33, 1523-1533.

Murphy, K.R., Stedmon, C.A., Waite, T.D., Ruiz, G.M., 2008. Distinguishing between terrestrial and autochthonous organic matter sources in marine environments using fluorescence spectroscopy. Mar. Chem. 108, 40-58.

Parlanti, E., Morin, B., Vacher, L., 2000. Combined 3D-spectrofluorimetry, high performance liquid chromatography and capillary electrophoresis for the characterization of dissolved organic matter in natural waters. Org. Geochem. 33, 221-236.

Patel-Sorrentino, N., Mounier, S., Benaim, J.Y., 2002. Excitation-emission fluorescence matrix to study $\mathrm{pH}$ influence on organic matter fluorescence in the Amazon basin rivers. Water Res. 36, 2571-2581.

Penna, A., Garcés, E., Vila, M., Giacobbe, M., Fraga, S., Lugliès, A., Bravo, I., Bertozzini, E., Vernesi, C., 2005. Alexandrium catenella (Dinophyceae), a toxic ribotype expanding in the NW Mediterranean Sea. Mar. Biol. 148, 13-23.

Pistocchi, R., Mormile, M.A., Guerrini, F., Lsani, G., Boni, L., 1997. Increased production of extra- and intracellular metal-ligands in phytoplankton exposed to copper and cadmium. J. Appl. Phycol. 12, 469-477.

Sellner, K.G., Doucette, G.J., Kirkpatrick, G.J., 2003. Harmful algal blooms: causes, impacts and detection. J. Ind. Microbiol. Biot. 30, 383-406.

Siu, G.K.Y., Young, M.L.C., Chan, D.K.O., 1997. Environmental and nutritional factors which regulate population dynamics and toxin production in the dinoflagellate Alexandrium catenella. Hydrobiologia 352, 117-140.

Stedmon, C.A., Bro, R., 2008. Oceanography methods characterizing dissolved organic matter fluorescence with parallel factor analysis: a tutorial. Environ. Res. 6, 572-579.

Sunda, W.G., Guillard, R.R.L., 1976. The relationship between cupric ion activity and the toxicity of copper to phytoplankton. J. Mar. Res. 34, 511-529.

Sunda, W.G., Hunstman, S.A., 1998. Processes regulating cellular and metal accumulation and physiological effects: phytoplankton as model systems. Sci. Total Environ. 219, 165-181.

Tessier, E., Garnier, C., Mullot, J.U., Lenoble, V., Arnaud, M., Raynaud, M., Mounier, S., 2011. Study of the spatial and historical distribution of sediment inorganic contamination in the Toulon Bay (France). Mar. Pollut. Bull. 62, 2075-2086.

Turki, S., Balti, N., 2005. Detection of toxic Alexandrium catenella (Whedon and Kofoid) balech in clam production zone of North Lake and Channel, Tunisia. Harmful Algae 28, 1-2.

Vasconcelos, M.T.S.D., Leal, M.F.C., Van der Berg, C.M.G., 2002. Influence of the nature of the exudates released by different marine algae on the growth, trace metal uptake and exudation of Emiliania huxleyi in natural seawater. Mar. Chem. 77, 187-210.

Vodacek, A., Blough, N.V., DeGrandpre, M.D., Peltzer, E.T., Nelson, R.K., 1997. Seasonal variation of CDOM and DOC in the Middle Atlantic Bight: terrestrial inputs and photo oxidation. Limnol. Oceanogr. 42, 674-686.

Zepp, R.G., Sheldon, W.M., Moran, M.A., 2004. Dissolved organic fluorophores in southeastern US coastal waters: correction method for eliminating Rayleigh and Raman cattering peaks in excitation-emission matrices. Mar. Chem. 89, 15-36. 